\title{
Dionysus and Ariadne in the light of Antiocheia and Zeugma Mosaics
}

Şehnaz Eraslan

\section{(2) OpenEdition \\ 1 Journals}

Electronic version

URL: http://journals.openedition.org/anatoliaantiqua/345

DOI: 10.4000/anatoliaantiqua.345

\section{Publisher}

IFEA

\section{Printed version}

Date of publication: 1 June 2015

Number of pages: $55-61$

ISBN: 9782362450600

ISSN: 1018-1946

\section{Electronic reference}

Sehnaz Eraslan, "Dionysus and Ariadne in the light of Antiocheia and Zeugma Mosaics », Anatolia Antiqua [Online], XXIII | 2015, Online since 30 June 2018, connection on 18 December 2020. URL : http://journals.openedition.org/anatoliaantiqua/345 ; DOI : https://doi.org/10.4000/anatoliaantiqua 345 


\title{
ANATOLIA ANTIQUA ESKI ANADOLU
}

\author{
XXIII
}

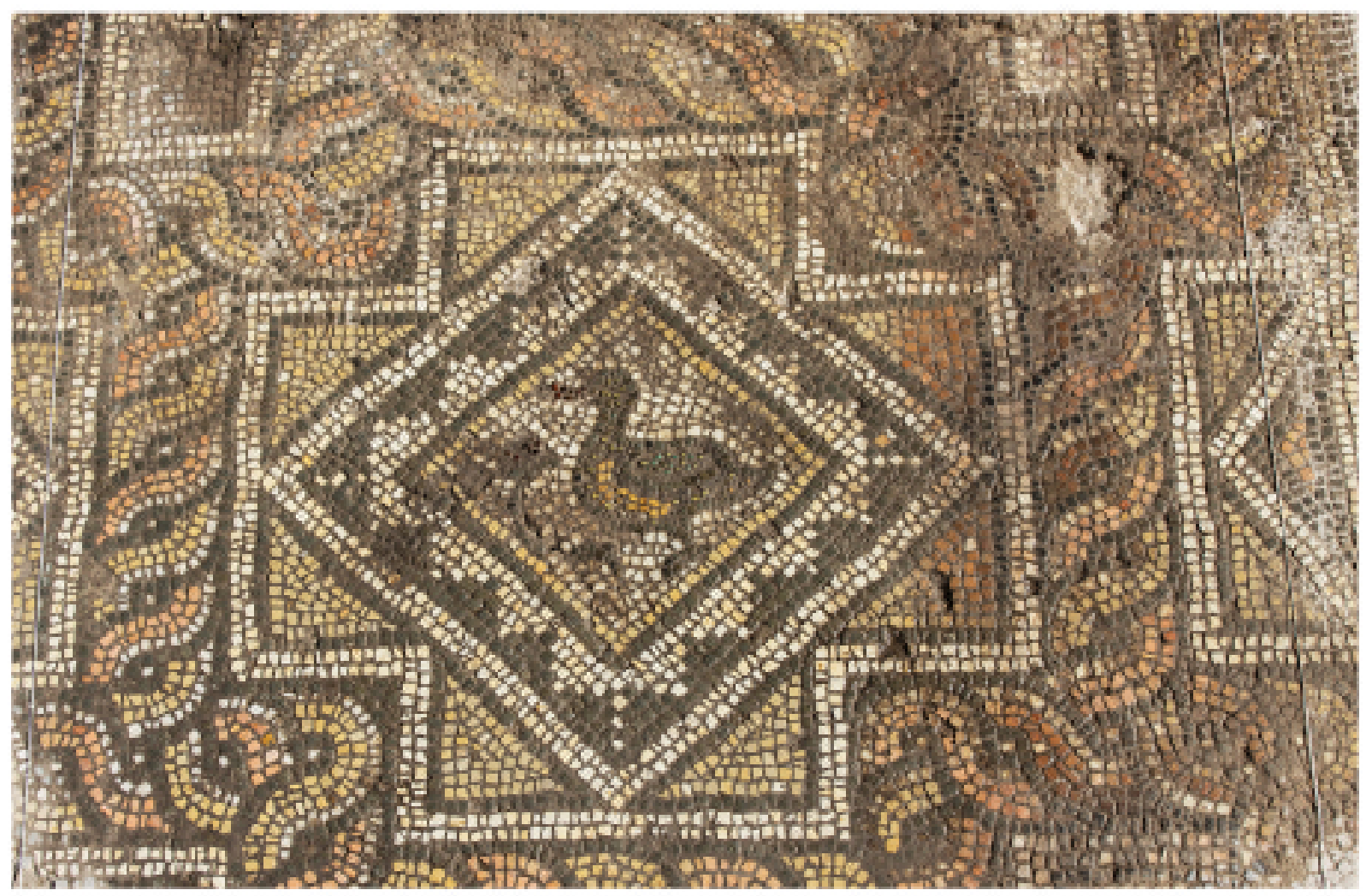

INSTITUT FRANC̣AIS D'ETUDES ANATOLIENNES GEORGES-DUMEZIL CNRS USR 3131 


\section{TABLE DES MATIERES}

Hélène BOUILLON,

On the anatolian origins of some Late Bronze egyptian vessel forms

Agneta FRECCERO,

Marble trade in Antiquity. Looking at Labraunda

Şehnaz ERASLAN,

Dionysus and Ariadne in the light of Antiocheia and Zeugma Mosaics

Ergün LAFLI et Gülseren KAN ŞAHIN,

Middle Byzantine ceramics from Southwestern Paphlagonia

Mustafa AKASLAN, Doğan DEMIRCİ et Özgür PERÇİN en collaboration avec Guy LABARRE, L'église paléochrétienne de Bindeos (Pisidie)

Anaïs LAMESA,

La chapelle des Donateurs à Soğanlı, nouvelle fondation de la famille des Sképidès

Martine ASSENAT et Antoine PEREZ,

Localisation et chronologie des moulins hydrauliques d'Amida. A propos d'Ammien Marcellin,

XVIII, 8,11

Helke KAMMERER-GROTHAUS,

$»$ Ubi Troia fuit«

Atzik-Köy - Eine Theorie von Heinrich Nikolaus Ulrichs (1843)

CHRONIQUES DES TRAVAUX ARCHEOLOGIQUES EN TURQUIE, 2015

Sami PATACI et Ergün LAFLI,

Surveys in Ardahan on the turkish-georgian borderline in 2013 and 2014

Çĭ̆dem MANER,

Preliminary report on the second season of the Konya-Ereğli survey (KEYAR) 2014

Dominique BEYER, Can KARAVUL, Françoise LAROCHE-TRAUNECKER et Aksel TiBBET,

Rapport préliminaire sur les travaux de la mission archéologique de Zeyve Höyük-Porsuk 2014

Jean-Charles MORETTI avec la collaboration de Nicolas BRESCH, Isabel BONORA,

Jean-Jacques MALMARY et Olivier RISS,

Claros, le temple d'Apollon : travaux réalisés en 2014

Olivier HENRY et Erika ANDERSSON, Christophe BOST, Ömür Dünya ÇAKMAKLI, Angela COMMITO, Mélissa CORMIER-HUGUET, Peter DE STAEBLER, Pierre DUPONT, Duygu ERGENÇ, Axel FREJMAN, Banu KEPENEK, Pascal LEBOUTEILLER, Haral NILSSON, Felipe ROJAS, Baptiste VERGNAUD, 


\section{DIONYSUS AND ARIADNE IN THE LIGHT OF ANTIOCHEIA AND ZEUGMA MOSAICS}

\section{INTRODUCTION}

Dionysus, the God of wine and an itinerant wandering around the world, is the last god welcomed to Olympia. The physical appearance of the God changed in every era and gained a new character. In time, he turned from the bearded god of agriculture and grape harvest of the Classical Age into an Apollo-type god with feminine lines. His attributes included the thyrsus and a drinking cup. His favourite animal is the leopard or occasionally tiger or lion. He was usually accompanied by dancing Satyrs, Bacchantes, Bacchic Erotes.

Themes related to Dionysus were used widely in mosaics of ancient cities of Antiocheia and Zeugma. They may be divided under five main headings. First are those which show scenes from the Dionysiac cult itself, with this generally associated the figure of Hermes or Nymphe. Next is a group representing the Triumph of Dionysus, riding in his chariot accompanied by his cortege. The third group includes depictions of Dionysus while he is drunk; in this group, Satyrs and Maenads accompany Dionysus. In the fourth group is the depiction of a wine contest held for Dionysus and Heracles; Dionysus was depicted as the winner of such contest. And the last one includes the depiction of relations between the God and Ariadne.

Theme of Dionysus and Ariadne was depicted admiringly within the art of archaic age as of $6^{\text {th }}$ century B.C. Such theme frequently depicted in vase paintings ${ }^{1}$, sarcophagus reliefs ${ }^{2}$ and in mosaics art. Portraits about Dionysus and Ariadne are separated into two main groups in terms of the scenes they depicted in mosaic art. These are, respectively, meeting of Dionysus and Ariadne in Naxos Island and the wedding feast of Dionysus and Ariadne.

\section{MEETING OF DIONYSUS AND ARIADNE IN NAXOS ISLAND}

As told by authors of ancient times, Ariadne played a role as the wife of Dionysus in Greek mythology ${ }^{3}$. According to mythology, Ariadne, the daughter of Crete King Minos, falls in love with Theseus and helps him out of the Minotaur labyrinth in return for marrying her. After killing the Minotaur, Theseus gets out of the labyrinth, takes along Ariadne and goes back to Athens. Ariadne wants to get off the ship docking to Naxos, and falls asleep on the coast. When she wakes up she realizes that Theseus has left her. Becoming sick at heart, Ariadne comes across with Dionysus in the coast, coming with his cortege. Dionysus takes Ariadne to Olympia and marries her; and he presents her the crown which will later become a star in the sky ${ }^{4}$.

The meeting of Dionysus and Ariadne in Naxos Island was depicted especially in the Eastern Mediterranean and North African regions. Sleeping Ariadne on Naxos was a popular scene in ancient art. Most of the figures in the panels have prototype series of Roman Imperial sarcophagi ${ }^{5}$. Except only for Sousse example, the other examples are thought to pattern their standard types of sarcophagi samples.

One of the scenes of meeting in Naxos was found Sousse in Tunisia (Fig. 1). However, this mosaic is different from other examples in terms of composition. In this composition, which reminds the theme called surprised nymph, we see Ariadne as standing, unlike other examples. In the panel, dated

\footnotetext{
*) Ministry of Culture And Tourism, General Directorate for Cultural Heritage and Museums, Ankara <erinonaz@hotmail.com>

1) Boardman 1975: fig. 229-269; McNally 1985: 152-192.

2) Etienne 1953: 365-368; Turcan 1966: 510-535; 1999: 98, fig. 107.

3) Hesiod, Theogony 947; Homer, Odyssey 11.320; Ovid, Metamorphoses 8.173; Nonnus, Dionysiaca 47.265.

4) Frécaut 1985: 151-163.

5) Turcan 1966: 510-535.
} 


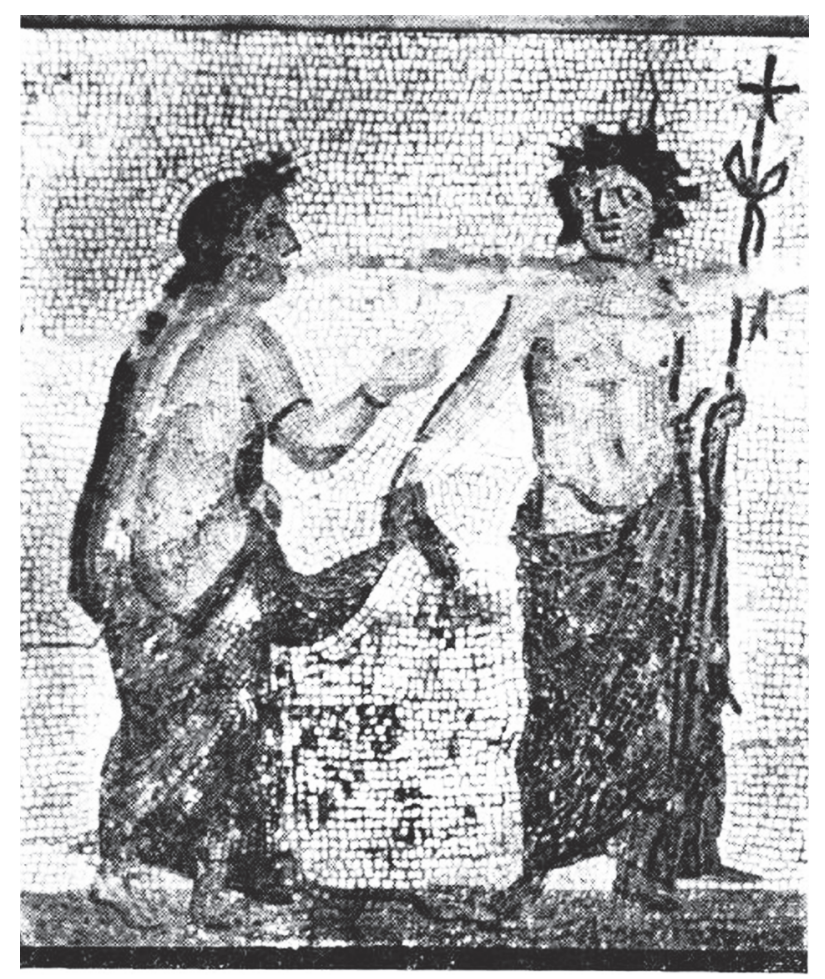

Fig. 1 : Dionysus and Ariadne, Sousse (Foucher 1957: pl. III, a).

back to middle $3^{\text {rd }}$ century A.D., Ariadne seems anxious, and Dionysus was depicted as heading towards her, to his new destiny. Themes, used in painting and sculpture repertoires of earlier times, were used later on by mosaic masters too. One of these themes includes a mortal woman, whose cloth was pulled up to her hips and upper part of her body remained uncovered, and a legendary hero or god carrying her away. In lineament, challenge, obedience or adoption may be depicted. Such theme called Surprised Nymph was adapted into many legends ${ }^{6}$.

Such theme is thought to have been derived from the popular painting of Nicomaque, one of the chiefs of Thébaine painting school, which called Bacchus surprised by Satyrs and painted in the first half of the $4^{\text {th }}$ century B.C. The erotic scenes in Hellenistic and Roman paintings and sculptures, in which Satyrs, various creatures and sometimes Nymphes, Maenads or Bacchants frightened by Pan himself were depicted, must be related to work of Nicomaque ${ }^{7}$.

The female body of Ariadne, lying on a rock and resting her right hand behind her head, in the scene
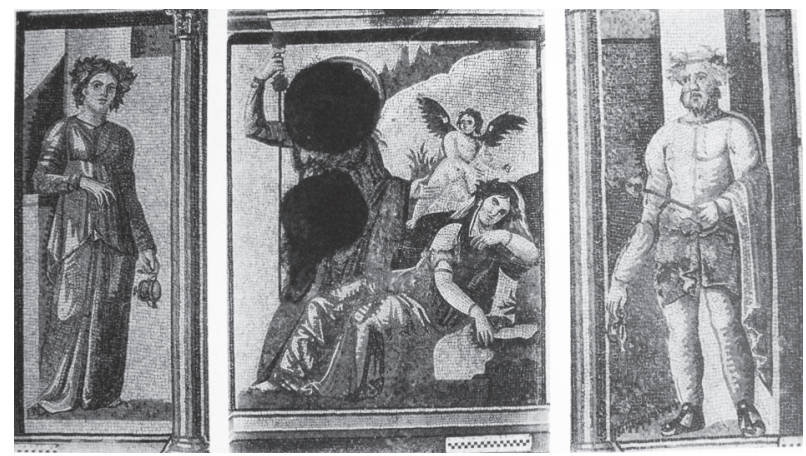

Fig. 2 : Dionysus and Ariadne, Antiocheia (Levi 1947: pls. XXVII-XXVIII).

of meeting of Dionysus and Ariadne in Naxos Island, and Eros pulling the sheet covering the legs of halfnaked woman and resting his hand similarly and lowering his head slightly are also depicted in sarcophagus reliefs. In Walters collection in Baltimore, the depiction of Dionysus and his wife Ariadne on a sarcophagus, found in Rome in 1885 and dated back to $2^{\text {nd }}$ century A.D., bears resemblances with frescoes in Pompeii. The only difference is the depiction of the extended left arm of Ariadne ${ }^{8}$.

One of the earliest examples of such scenes has been found in Antiocheia (Fig. 2). In the House of Dionysus and Ariadne Triclinium floor has a large rectangular panel within a geometric border. Mosaic dated back to the period between the $2^{\text {nd }}$ and $3^{\text {rd }}$ centuries A.D. ${ }^{9}$. In the central part is the scene Dionysus and Ariadne in Naxos. Ariadne sleeps half reclining on an elevation of the ground. Dionysus stands at her side and holds a thyrsus decorated with a pine cone. It seems like a naked Eros stands between Ariadne and Dionysus, heading towards Ariadne. On the left side, there is a Maenad on pedestal. There is a crown on the head of the Maenad, wearing chiton; she holds a cup in her left hand and a Satyr stands on the right side with a thyrsus in his left hand. One of the most remarkable aspects of mosaics of Antiocheia is the emphasis put on perspective and three-dimensional form in figures. The existence of light and shadow was provided in colour transitions and accordingly the figures gained form. As in Hellenistic paintings, the figures were depicted in a realistic manner and segregation between foreground and background was provided.

In a mosaic with the sleeping Ariadne myth dating from around the first half of the $4^{\text {th }}$ century A.D. ${ }^{10}$

6) Foucher 1957: 151-161, pl. III a.

7) Labrousse 1938: 78-95.

8) Labrousse 1938: 78-95

9) Levi 1947: 142-143, pls. XXVII-XXVIII; Cimok 2000 : 124-128.

10) Dunbabin 1999: 215, fig. 226. 


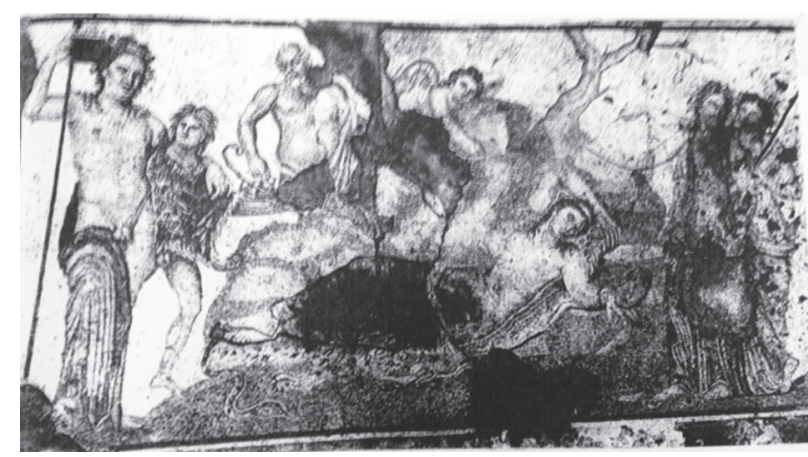

Fig. 3 : Dionysus and Ariadne, Thessalonica (Dunbabin 1999: 215, fig. 226).

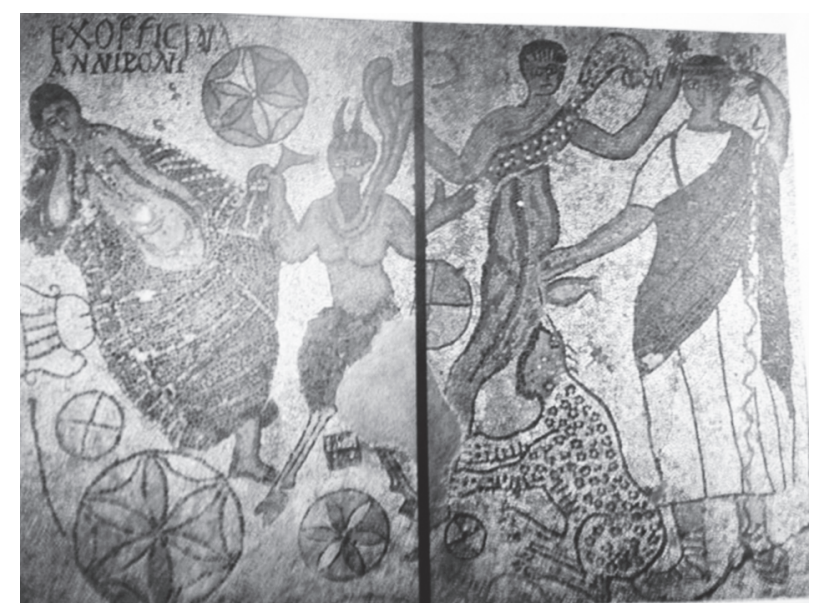

Fig. 4 : Dionysus and Ariadne, Augusta Emerita (Blazquez and Cabrero 2012: 47, fig. 4).

found in Thessalonica, Ariadne was depicted as fallen asleep and Dionysus was depicted together with his cortege next to Ariadne (Fig. 3). It has a similar style and composition with Antiocheia example. The effort of creating a three dimensional effect is noticed. Trees behind Ariadne and Eros depicted on the rock are the most distinctive example of such effort. In both of these examples, idealization of mythological scenes and figures composed within Hellenistic tradition, and effort of creating a three dimensional effect by colour transitions are observed.

Similar Dionysiac scenes and figures are found on mosaics throughout the Empire; one of these examples was found in the capital of Lusitania, Augusta Emerita ${ }^{11}$ (Fig. 4). In the figures of the mosaic, dated back to the $4^{\text {th }}$ century A.D., local workshop effect attracts the attention in general. In the top left corner of the panel, Ariadne sleeps resting on her

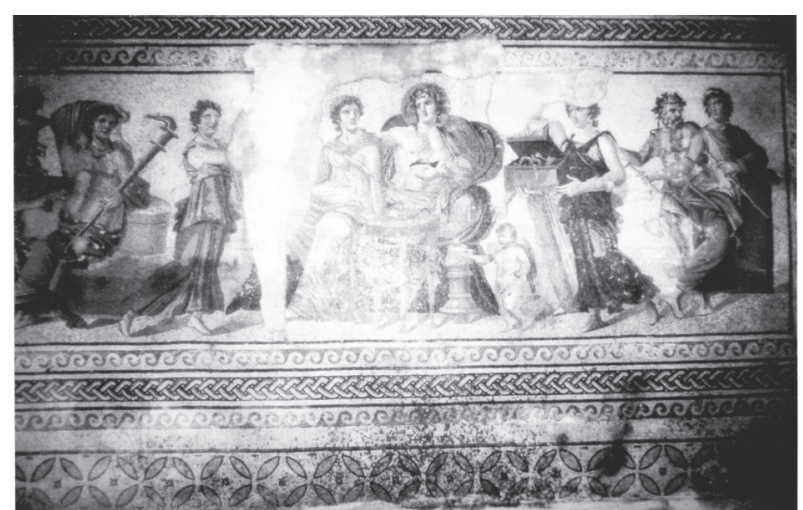

Fig. 5 : Dionysus and Ariadne, Zeugma (Abadie-Reynal 2002: 748-749, fig. 4).

right hand and there are Pan and Satyr to her right side; in the top right corner of the mosaic, Dionysus pours wine from the pot in his right hand and holds thyrsus in his left hand. It is understood that Augusta Emerita example was depicted differently in terms of composition and style. Pan and panther, not seen in Antiocheia example, take up large part of the panel. In terms of style, the most significant difference is the fact that three-dimensional effect is not felt. The figures were depicted superficially, not in form. Linearity in figures limited the form and it seems as if a single contour was drawn. The classical forms idealized in Antiocheia example gave way to linearly-depicted figures here.

\section{WEDDING OF DIONYSUS AND ARIADNE}

Celebratory wedding ceremony held after Dionysus had found Ariadne in Naxos Island, were depicted frequently in Dionysus themed compositions. We can often see theme of Dionysus and Ariadne marriage not only in mosaics but also in ivory reliefs, vase paintings and coloured fabrics of the period. In all of such depictions, Ariadne and Dionysus sit on a throne next to each other ${ }^{12}$.

One of the earliest examples of such composition was found in the House of Dionysus and Ariadne Mosaic in Zeugma (Fig. 5). The gallery to the west of the peristyle courtyard of the house was covered later and used as a hall or a reception room. The basement of this hall was adorned with a splendid mosaic with the theme of Dionysus and Ariadne marriage ${ }^{13}$. The whole building was dated back to the end of $2^{\text {nd }}$ century and beginning of $3^{\text {rd }}$ century

11) Dunbabin 1999: 158, fig.163; Alvarez Martinez 2001: 140-141; Blazquez and Cabrero 2012: 44-47, fig. 4.

12) LIMC III, 2 1986: 406-419.

13) Abadie-Reynal 2002: 748-749, fig. 4. 


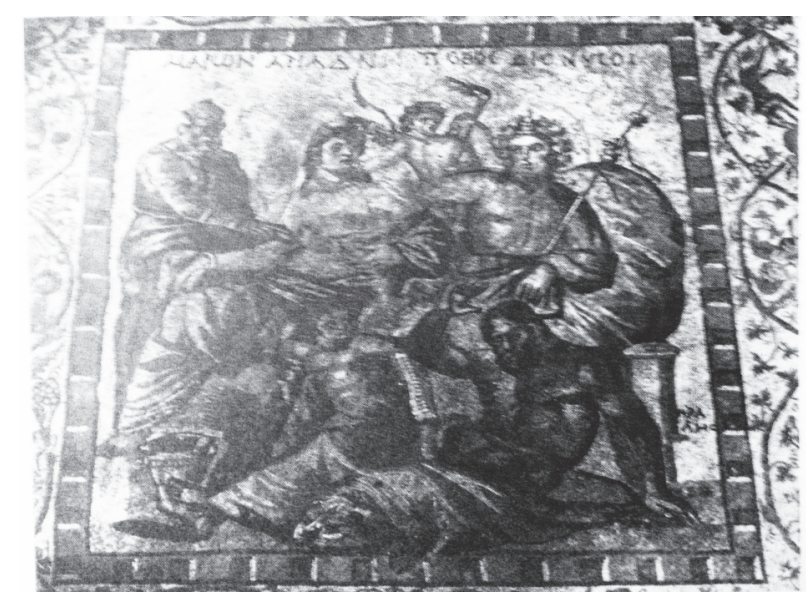

Fig. 6 : Dionysus and Ariadne, Shahba

(Balty 1977: 50-56, fig. 20-23).

A.D. ${ }^{14}$. Such mosaic is the most figurative one among all Ariadne themed mosaics. The larger part of the mosaic was stolen in 1988 and the remaining parts are on display at Zeugma Mosaic Museum. To the leftmost of the panel is Satyr drinking wine with a bowl. In these cases the Satyr, sometimes holding a crater, supports a drunken Dionysus, who leans back on his companion. Next to Satyr, the Maenad was depicted with a Hymene style torch in her hands. Flame of such torch symbolizes the passion uniting couple together. The other Maenad to the right of the couple walks towards the right and carries with her raised arms an instrument or thyrsus. Figures of Maenads while carrying the thyrsus are also confronted in Ariadne themed sarcophagi ${ }^{15}$. Therefore, it is possible for the Maenad there to carry a thyrsus. In the centre of the panel are Ariadne sitting on a throne, Dionysus with a halo around his head, Eros next to the throne, two Maenads walking towards the left; and to the rightmost is a Maenad holding a flute with her both hands, and behind her is a shock-head and bearded Satyr whose upper body is naked.

A similar example was found in PhilippolisShahba Syria (Fig. 6). Dated back to the second quarter of the $4^{\text {th }}$ century A.D., this mosaic is now on display in Philippolis-Shahba Museum ${ }^{16}$. Decorating one of the side-rooms of ancient villa, the mosaic includes scenes of a series of characters related to Dionysus theme and whose names were also writ- ten. In the centre of the panel is the depiction of Ariadne, sitting with Dionysus on a rock, as seen in the traditional love talk scheme: chests and legs of both of them are naked and their left arms are covered with cloth. The young woman wears jewels such as bracelets, earrings, necklaces and diadem, she holds a cup in her left hand; and the God Dionysus is seen as resting her shoulder and holding thyrsus. Behind the couple is the depiction of Eros holding a Hymene style torch. In the forefront, Heracles sits by leaning on his left arm in a drunk and overbalanced way. A Putto, next to him, tries to hold him. Upper body of Heracles is naked and lower parts are covered. The last character depicted in this scene is a flap-eared old one with Satyr-type to the leftmost of the panel. If it had not been written "Maron" on the mosaic, we may have thought that it was a Silene. Janine Balty states that this mosaic bears the characteristics of Constantine Renaissance style ${ }^{17}$. In the style called Constantine Renaissance which dominates in the second half of $4^{\text {th }}$ century A.D., classical models were again in use. The most characteristic features of the style are calm appearances of figures, shapely facial lines and the importance given to details ${ }^{18}$.

It can be said that the scene bears resemblances with Zeugma example in terms of iconography. Such resemblance is noticeable especially in positions and styles of Ariadne and Dionysus. The slight aureole behind Dionysus, the fabric revealing his chest but covering his left shoulder, the light and shadow contrast in the fabrics, Dionysus hugging Ariadne with his right arm, face-to-face position of the couple, eyebrow, eye and lineaments of depicted characters can be specified as similarities. Besides such similarities, the objects in the hands of couples change. In the mosaic in Shabba Syria, the cup is in Ariadne's hand, but in the mosaic in Zeugma it is in Dionysus hand. Another difference is remarkable in other characters depicted in the scene. In Zeugma example, the characters are in a mobility and excitement; but in Shahba example, the figures are calm.

We understand that Dionysus and Ariadne was a popular theme in Zeugma. We see this theme in the mosaic found on the ground of Living Room of House of Euphrates, which depicts Dionysus and Ariadne sitting next to each other (Fig. 7). Dated back to the period between the $2^{\text {nd }}$ and $3^{\text {rd }}$ centuries A.D., this mosaic is on display in Zeugma Mu-

14) Campbell and Ergeç 1998: 115.

15) Turcan $1966: 510-535$; Kondoleon 1995: 196.

16) Balty 1977: 50-56, fig. 20-23.

17) Balty 1977: 52, fig. 20-23.

18) Dunbabin 1999: 166. 


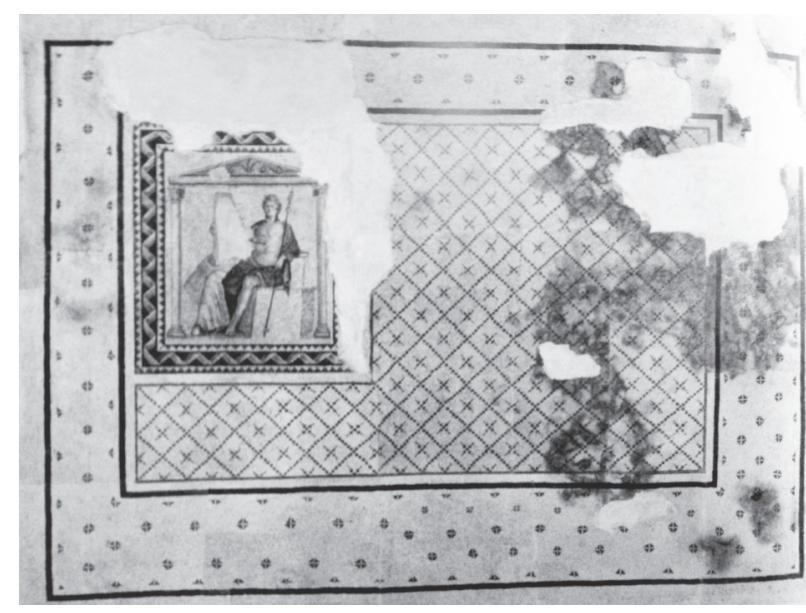

Fig. 7 : Dionysus and Ariadne, Zeugma

(Önal 2008: 88, fig. 11-12).

seum $^{19}$. In this triangular-facade and double column building, Dionysus and Ariadne were depicted as sitting. Both figures were depicted in the same way as if drawn from a single mould. Depiction of Ariadne sitting next to Dionysus is in the centre of the panel: left feet of both of them were depicted ahead and right feet behind. Most probably, Dionysus hugs Ariadne with his right arm and upper part of Ariadne has been destroyed. But, she must have turned her face towards the God. Chest of Dionysus is naked but his arms are clothed. He rests his thyrsus on his left shoulder. While figurative panels were made into the centre in other rooms, here the panel is at the south-western corner. It seems as if a carpet was rolled out onto room floor. The mosaic was adorned with a simplified landscape or a non-figurative background beautified with flowers. In mosaics usage of environmental decoration and perspective-free isolated motifs, stylized people, regular repetition of motifs, reverse depicted motifs and covering the whole surface only for decoration purposes are influences belonging to Sassanid $\operatorname{art}^{20}$. Maybe, Zeugma mosaics display the initiation of eastern influence in the Mediterranean world; we see mosaics in Antiocheia made totally for decoration purposes towards the end of $5^{\text {th }}$ century A.D.: flowers, leaves of trees, pigeons are motifs which were frequently used in mosaics. Perhaps, in the Roman world, such kind of new style mosaics were made firstly in Antiocheia and Zeugma.

One of the mosaics with the theme of Dionysus and Ariadne sitting on a throne was found in

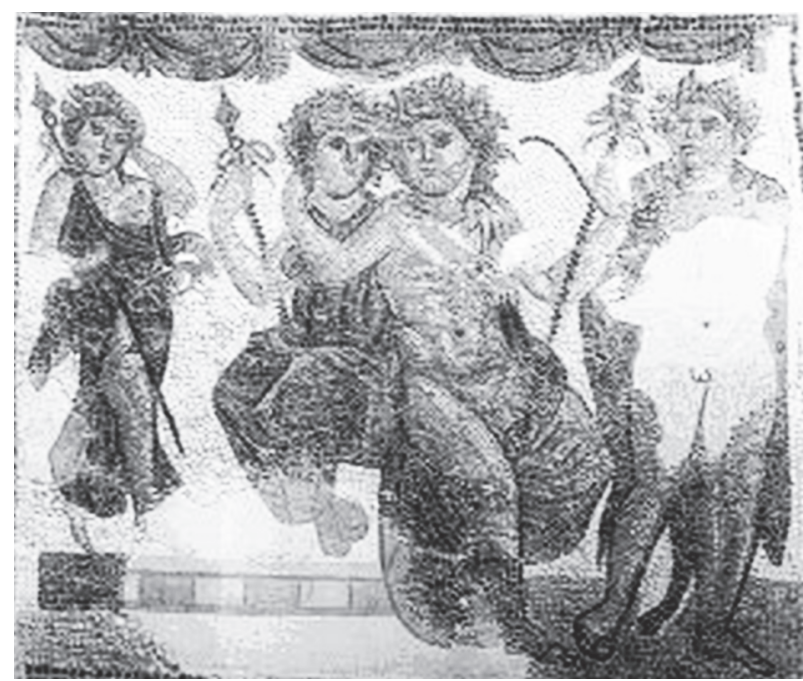

Fig. 8 : Dionysus and Ariadne, Thuburbo Majus (Alexander, Khader and Soren 1994: 102-104, pl. LVI (419)).

Thuburbo Majus, Tunisia (Fig. 8). Dated back to the first half of the $4^{\text {th }}$ century A.D., the mosaic is now on display in Bardo Museum ${ }^{21}$. In the left part of the panel is Maenad; in the centre are Ariadne and Dionysus in a sitting position; Ariadne to the right and Dionysus to the left. A Satyr accompanies them in the right part of the panel. The faces of the couple turn to each other; and Dionysus is almost naked and in the forefront. Dionysus hugs Ariadne with his right hand; and Ariadne holds a thrysus with her right hand. There is a crown on her head, bejewelled with vine leaves. Lower half of Dionysus' body is covered except for the right leg; he wears green boots. Ariadne is depicted as sitting behind Dionysus; their hairs touch each other. Contrary to Dionysus, Ariadne wears a long tunic; only her arms and feet are seen. The thrysus in her hand is different from the Dionysus' thrysus ; it has no vine leaves.

Wedding scenes of Dionysus and Ariadne were generally depicted while they are sitting on a throne or floor. However, there are also examples in which the couple was depicted as a bust. Besides mosaics, such depictions of the couple are generally confronted in rugs and frescoes. One of them can be seen on rugs which are thought to have been made during $5^{\text {th }}-6^{\text {th }}$ centuries A.D. in Egypt ${ }^{22}$. In these figures, Dionysus turns his face to the right, his upper body is either completely naked or covered with a cloak; his hair is curly and there is an aureole on his

19) Önal 2008: 88, fig. 11-12.

20) Lassus 1936: 33-42.

21) Alexander, Khader and Soren 1994: 102-104, pl. LVI (419).

22) LIMC III,2 1986: 417, nr. 123, 124. 


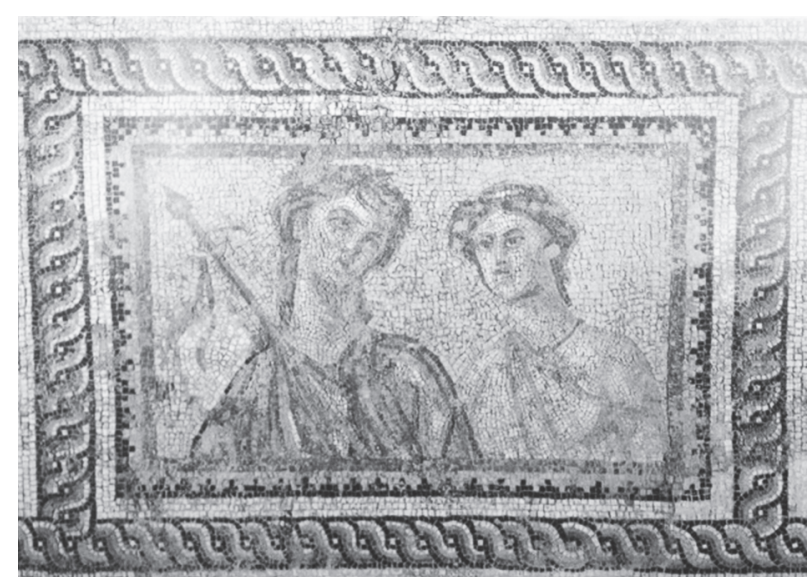

Fig. 9 : Dionysus and Ariadne, Antiocheia (Levi 1947: 220, pl. XLIC, c).

head. Ariadne, on the other hand, turns her head towards the left; her hair was stylized with diadem; and she wears a necklace and clothe. We can see bust depictions of the couple in mosaics of Antiocheia ${ }^{23}$ (Fig. 9) and Ephesus ${ }^{24}$ (Fig. 10). As noted by Doro Levi their bust are often used for decorative purposes, in small panels or medallions, together with bust of Satyrs and Bacchantes, as early as Pompeian painting 25 .

\section{CONCLUSION}

Dionysus was accepted by the Greek people as an eastern god then due to the fact that the mother of Dionysus was a Thracian woman. Attributed to the east, this god was accepted highly in Anatolia with respect to mythological and characteristic descriptions; and he was mentioned within various themes. Expansion of Ariadne and Dionysus theme in the eastern part of the Empire by means of mosaics, which are related to our subject, is important in terms of demonstration of such influence. The lan-

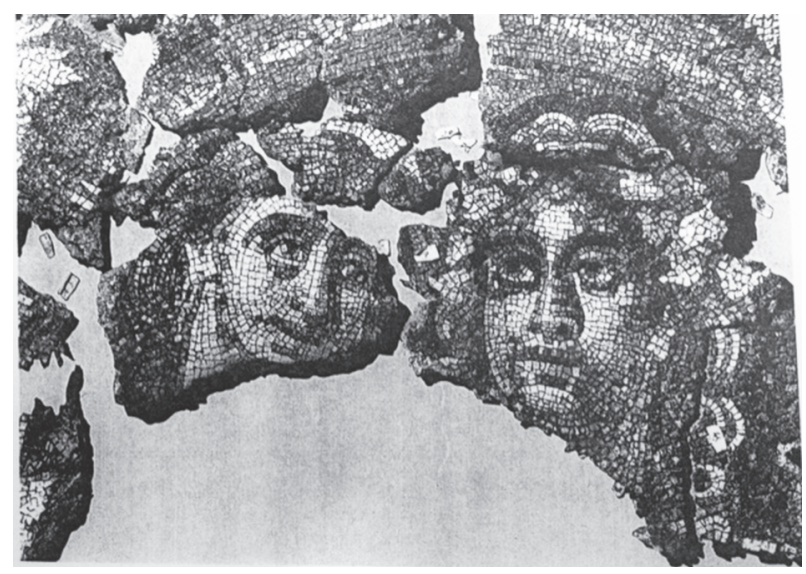

Fig. 10 : Dionysus and Ariadne, Ephesus (Jobst 1975: 73, fig. 115-116).

guage most widely spoken was Greek. Social life retained the forms of the Hellenistic age. It is perhaps not surprising, therefore that in parts of the East mosaics styles continued to reflect the Greek emblema tradition. Therefore, we can suggest that they abided by Hellenistic tradition in mosaics and they depicted their gods with a divine characteristic, beyond a mere mythological description. Mosaics about the coupling of Dionysus and Ariadne were firstly found in Antiocheia and Zeugma during the $2^{\text {nd }}$ and $3^{\text {rd }}$ centuries A.D.; and expanded across Eastern Mediterranean and Northern Africa regions during the $3^{\text {rd }}$ and $4^{\text {th }}$ centuries A.D. Without doubt, such expansion is thought to have been resulted from the travels of mosaic masters due to commercial ties between regions having a coast on the Mediterranean, or by means of draft mosaic books. Our research gives rise to the thought that coupling of Dionysus and Ariadne in mosaics sprang from Antiocheia and Zeugma.

Ş. E. 


\section{BIBLIOGRAPHY}

Abadie-Reynal, C., 2002: "Les maisons à décors mosaïqués de Zeugma", Comptes-rendus des séances de l'Académie des Inscriptions et Belles-Lettres 146: 743771.

Alexander, M. A., Khader, A. B and Soren, H. D., 1994: Corpus des Mosaïques de Tunisie. Thuburbo Majus: les mosaïques de la région est. Mise à jour du catalogue de Thuburbo Majus, et, Les Environs, les mosaïques de Ain Mziger, Bir Chana, Draa Ben Jouder et Zaghouan, Institut nationale du patrimoine, Tunis.

Alvarez Martínez, J. M., 2001: Mosaico romano del Mediterráneo, Madrid. elles.

Balty, J., 1997: Mosaïques Antiques de Syrie, Brux-

Bingöl, O., 1997: Malerei und Mosaik der Antike in der Türkei, Philipp von Zabern, Mainz/Rhein.

Blazquez, J. M. and Cabrero, J., 2012: “Antiocheia Mosaics and their Mythological and Artistic Relations with Spanish Mosaics", Journal of Mosaic Research 5, Istanbul.

Boardman, J., 1975: Athenian Red Figure Vases, the Archaic Period: A Handbook, Thames \& Hudson, London.

Campbell, S. and Ergeç, R., 1998: "New Mosaics Rescue Excavations by the Gaziantep Museum (19921994)", in: The Twin Towns of Zeugma on The Euphrates: Rescue Work and Historical Studies, Portsmouth: 109128. bul.

Cimok, F., 2000: Antioch Mosaics, A Turizm, Istan-

Dunbabain, K. M. D., 1999: Mosaics of the Greek and Roman World, Cambridge University Press, Cambridge.

Ergeç, R., 1998: "Rescue Excavations by the Gaziantep Museum (1992-1994)", in: The Twin Towns of Zeugma on The Euphrates: Rescue Work and Historical Studies, Portsmouth: 81-91.

Etienne, R., 1953: "Les sarcophages romains de Saint-Médard-d'Eyrans", Revue des Etudes Anciennes 54: 365-368

Foucher, L., 1957: "La mosaïque dionysiaque de Themetra", Mélanges d'archéologie et d'histoire 69: 151161.

Frécaut, J.-M., 1985: "Un personnage féminin dans l'œuvre d'Ovide: Ariane", in: La femme dans le monde méditerranéen. I. Antiquité, Maison de l'Orient et de la Méditerranée, Lyon: 151-163.
Hesiod.Theog. (= Hesiodos,Theogonia): Theogony. With an English translation by M. L.West, Oxford 1966. Hesiodos, Theogonia, Eseri ve Kaynaklarl, Trad. S. Eyüboğlu-A. Erhat, Ankara 1991.

Hom. Od. (= Homeros, Odysseia): Odysseia, Trad. A. Erhat - A. Kadir, İstanbul 1988.

Jobst, W., 1977: Römische Mosaiken aus Ephesos. Die Hanghäuser des Embolos, Verlag der Österreichischen Akademie der Wissenschaften, Wien.

Kondoleon, C., 1995: Domestic and Divine: Roman Mosaics in the House of Dionysos, Cornell University Press, Ithaca and London.

Labrousse, M., 1938: "Une mosaïque inédite du musée de Brive (Corrèze)", Mélanges d'archéologie et d'histoire 55: 78-95.

Lassus, J., 1936: "Les mosaïques d'Antioche", Comptes-rendus des séances de l'Académie des Inscriptions et Belles-Lettres 80: 33-42.

Levi, D., 1947: Antioch Mosaic Pavements, Princeton University Press, Princeton.

McNally, S., 1985: Ariadne and Others: Images of Sleep in Greek and Early Roman Art Classical Antiquity, University of California Press Stable 4: 152-192.

Ovid. Met. (= Ovidius, Metamorphosis): Dönüşümler, Trad. İsmet. Z. Eyüboğlu, Payel Yayınevi, 1997.

Önal, M., 2008: "Euphrates Evinin Mozaikleri”, The proceedings of IV. International Mosaic Corpus of Turkey. The Mosaic Bridge from Past to Present, Uludağ University Press, Bursa.

Raymond, T., 1948: "Mosaïque dionysiaque trouvée au Maroc", Comptes-rendus des séances de l'Académie des Inscriptions et Belles-Lettres 92: 348-353.

Reinach, S., 1922: Répertoire de peintures grecques et romaines, Paris.

Scheibelreiter, V., 2008: "Gold from Ephesus: The Evidence of a Dionysus-Mosaic in Terrace House 2", The proceedings of IV. International Mosaic Corpus of Turkey. The Mosaic Bridge from Past to Present, Uludağ University Press, Bursa.

Turcan, R., 1966: Les sarcophages romains à représentations dionysiaques. Essai de chronologic et d'histoire religieuse, De Boccard, Paris.

- 1999: Messages d'outre-tombe. L'iconographie des sarcophages romains, De Boccard, Paris. 


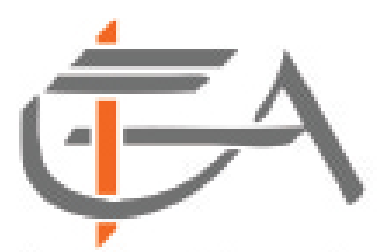

Institut Français d'Etudes Anatoliennes

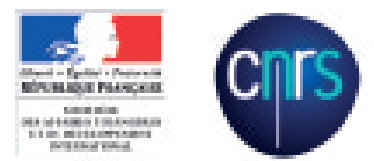

Eglise paléochrétienne de Bindéos (Pisidie), détail de la mosaïque ornant le sal de la nef centrale, $4^{e} \mathrm{~s}$. ap. J.-C. 